\title{
Notes on the Life Cycle of the Tobacco Hornworm, Manduca sexta (L.) (Lepidoptera; Sphingidae), in Puerto Rico'
}

\author{
Rafael Inglés Casanova and Silverio Medina Gaud ${ }^{2}$
}

\begin{abstract}
The life cycle of the sphingid moth, Manduca sexla (L.), the tobacco hornworm, was investigated in Puerto Rico. Descriptions of the stages, including measurements of the egg (length and width), larva (length and head capsule width), pupa (length), and the duration of each of the stages are given. The estimated leaf consumption by each larval instar, a list of known host plants, and the natural enemies known to occur in Puerto Rico are included.
\end{abstract}

\section{INTRODUCTION}

Gross income from the tobacco crop in Puerto Rico for 1971-72 (1) was about $\$ 2,847,983$. Profitable tobacco yields are difficult to obtain without careful and planned cultivation, with pest control a most essential aspect.

This crop is attacked by many insect species, but the tobacco hornworm is the most important and thus a limiting factor in local production. According to Madden and Chamberlain (11), the species occurs from southern Canada throughout the tobacco growing areas of continental United States, Central America, West Indies and south to southern Argentina. The larva of this moth destroys the young plants in the field and eats portions of the older leaves, thus reducing their commercial value.

The purpose of this research was to develop a better local knowledge of the life cycle of the insect and the duration of its various stages to provide practical information for timing application of control measures. No complete study of the life cycle of Manduca sexta, nor measurement of leaf consumption (by area), has been conducted in Puerto Rico.

\section{REVIEW OF LITERATURE}

The scientific name of the insect, commonly known as the hornworm, the tobacco hornworm, the tomato hornworm, and in Spanish "el cornudo del tabaco" and "el gusano verde del tabaco", is Manduca sexta (L.), although known as well by other names now in synonymy in earlier scientific

1 Manuscript submitted to Editorial Board May 23, 1974.

2 Research Assistant and Associate Entomologist, respectively, Department of Entomology, Agricultural Experiment Station, Mayagūez Campus, University of Puerto Rico, Rio Piedras, P.R. The authors express their appreciation to Dr. L. F. Martorell, Professor Emeritus, Department of Entomology, Agricultural Experiment Station, for his suggestions in the preparation of this manuscript. 
literature. It has been known as a pest of economic importance in tobacco and other solanaceous crops in Puerto Rico since the early days when tobacco cultivation was initiated in the Island. Dewits (5) in 1877 first recorded it in Puerto Rico as Macrosila carolina L. Stahl (16) listed it five years later under the same name. Gundlach (6) in 1887 and Möschler in 1890 (13) recorded the species as Sphinx carolina L., the former author noticed it as a potential pest of tobacco and tomato orchards.

As a tobacco pest, Busck (3) in 1899 and Barrett (2) in 1905, listed this insect from the Island under the name of Phlegethontius carolina $\mathrm{L}$. Tower (17) in 1908 reported the economic damage caused by this pest to tobacco and he recorded the hymenopterous wasp, Teleonomus sphingis Ashmead, then known as T. moniliconnis Ashmead, as a parasite of the eggs. Jones (7) in 1915 and Cotton (4) in 1919 listed the species as Phlegethontius sexta Johansson and Protoparce sexta Johansson, respectively, and both described the damage the species causes to vegetables. Wolcott (18) in 1922 called it Phlegethontius sexta jamaicensis Butler, furnished a brief account of the duration in days of its several stages and mentioned control measures then available. He illustrated the several larval stages and also contributed a drawing of a local predatory bird locally known as "mozambique", Quiscalus niger brachypterus, with a larva in its beak.

Wolcott $(20,23)$ in 1924 and 1933 furnished information on the economic aspects and an illustrated account of the damage caused by this insect. He reported in 1924 (21) having fed the larva to the lizard, Ameiva exul, in captivity and in 1925 (22) that the dry weight of the adult was about one-tenth the weight of the food consumed by the larva. Half of the loss in weight of the larva he found to occur during its transformation from larva to adult. Rosenfeld (15) in 1925 recorded the attack to adults by the lizard, Anolis cristatelus. Leonard $(9,10)$ in 1931 and 1932, respectively, reported the amount of damage caused by this insect to tobacco in Puerto Rico. Wolcott, during 1923 and $1936(19,24)$ furnished an account of all previous Puerto Rican records for this species and listed it from various localitics under the name of Phlegethontius sextus Johansson var. jamaicensis Butler, a name which he changed in 1948 (25) to Phlegethontius (or Protoparce) sextus Johansson var. jamaicensis Butler.

\section{MATERIALS AND METHODS}

Life cycle studies were conducted during April and May 1973 starting with field-collected eggs from tobacco plants grown at the Gurabo Agricultural Experiment Substation. Larvae were reared during these months on tobacco leaves. Data obtained for the duration of life cycle stages, measurement of head capsules, and amount of leaves consumed in terms of square centimeters by the different larval stages are given in tables 1 to 3 . The 
duration of the egg stage and prepupal period were not taken into consideration during the April rearing.

\section{APRIL REARING}

Two hundred eggs of unknown age were collected from a tobacco field for laboratory rearing during April 1973. Of these, 100 larvae of known instars were reared, killed in KAAD and preserved in 70 percent alcohol, for measurement purposes. The individual eggs laid on the leaves were separated within small pieces of tobacco leaves ( 25 to $50 \mathrm{~cm}^{2}$ in size) and placed in $2.3 \times 9.5 \mathrm{~cm}$ glass vials, covered with wet cotton plugs and incubated at $79^{\circ} \mathrm{F}$. The duration of each instar was recorded and, the head capsules saved for future measurements. Third instar larvac were transferred to larger glass vials, and those of the 5th instar to 1-liter capacity jelly jars. Pieces of leaves (50 to $200 \mathrm{~cm}^{2}$ ) were used to feed 4th instar larvac; each of the 5th instar larva required more than an entire leaf per day. The pupal stage took place in sterilized sand moistened with distilled water in the jelly jars. A piece of wire was placed inside each jar so the emerging adult could cling to it, thus facilitating stretching of wings. Once the adults emerged, they were transferred to wooden cages and fed with a 15 percent honey solution.

\section{MAY REARING}

A series of tobaceo leaves were marked previously in the field to assure freedom from eggs. The next day the field was visited again and $10 \mathrm{eggs}$ collected. However, 20 more eggs of different ages were collected on the unmarked foliage and preserved in 70 percent alcohol for later measurement. lrom the first group of eggs, 10 larvae were obtained; each one was placed in a separate container in which werc pre-measured pieces of leaves to determine the amount of foliage consumed by each larva throughout its different instars. The leaf pieces frequently had to be changed one or more times to provide the larvae with fresh feeding material and also to assure a continuous feeding process. The leaves were photographed previously by using ammonia paper and the area caten measured later with a planimeter.

The April and May technique was the same for rearing adults.

\section{DESCIRIYTION OF STAGES}

LGG STAGE

The eggs are laid singly. Oviposition normally orcurs on the lower surfare of the tobaceo leaves, usually near the tip. Eggs also are deposited elsewhere on the plant.

The egg (fig. 1) usually is oval; noarly spherical in some cases. It has a 
smooth surface. The color when first deposited may vary from glossy lightto flat-green, changing later to ycllow and finally turning bone-white just prior to hatching. These observations agree with those of Madden and Chamberlain (11).

The duration of the egg stage averaged 4.5 days (table 2). Twenty eggs averaged $0.79 \mathrm{~mm}$ in length and $0.70 \mathrm{~mm}$ in width (table 1), and according to Wolcott (22), weighs approximately $0.001 \mathrm{~g}$.

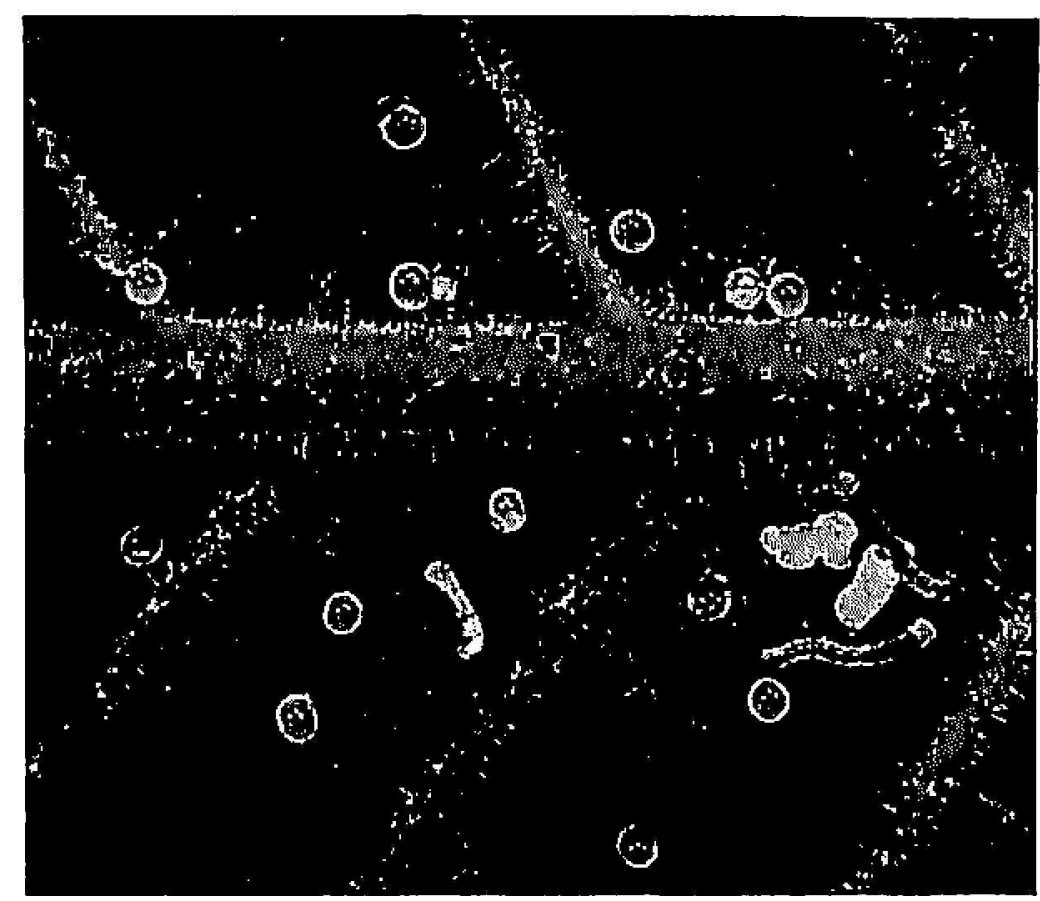

Fig. 1.--Eggs and newly hatched larvae of tobacco hornworm on tobacco leaf.

\section{LARVAL STAGES}

The grown larva (fig. 2) in general consists of a cylindrical body densely covered with fine hairlike setae, and is equipped with biting mouth parts, a pair of true legs on each of the three thoracic segments, and a pair of prolegs on the third, fourth, fifth, sixth, and last abdominal segments in all larval instars. The prothoracic segment bears one pair of spiracles and additional pairs oceur on the first eight abdominal segments. The eighth abdominal segment is tipped with a dorsocaudal horn.

Data on the average duration of the five instars, measurements on the length of the larvae, head capsules and averages of leaf area consumption are given in tables 1,2, and 3 .

Firsl Instar

Newly hatehed larsare are yellowish-white. The color changes to lightgreen soon after feeding starts. The dark-brown dorsocaudal horn is nearly 
TABLE 1.-Size of field-collecled eggs, larval and pupal length, and head capsule width of the tobacco hornworm, Manduca sexta (L.), April and May 1978

\begin{tabular}{|c|c|c|c|c|c|c|c|c|c|}
\hline \multirow{2}{*}{ Stage } & \multicolumn{3}{|c|}{ Width (mm) } & \multicolumn{3}{|c|}{ Length $(\mathrm{mm})$} & \multicolumn{3}{|c|}{$\underset{(\mathrm{mm})^{\mathrm{l}}}{\text { Head capsulth }}$} \\
\hline & Min. & Ave. & $\operatorname{Max}$ & Min. & Ave. & Max. & Min. & Ave. & Max. \\
\hline Egg $^{2}$ & 0.66 & 0.70 & 0.74 & 0.74 & 0.79 & 0.88 & - & - & - \\
\hline \multicolumn{10}{|l|}{ Larvae $^{3}$} \\
\hline 1st & - & - & - & 4.0 & 9.0 & 11.0 & 0.7 & 0.7 & 0.8 \\
\hline 2nd & - & - & 一 & 10.0 & 15.0 & 18.0 & 1.1 & 1.1 & 1.3 \\
\hline 3rd & - & - & - & 19.0 & 21.0 & 25.0 & 1.6 & 1.8 & 2.0 \\
\hline 4 th & - & - & - & 25.0 & 32.0 & 44.0 & 2.9 & 3.1 & 3.5 \\
\hline 5th & - & - & - & 52.0 & 66.0 & 87.0 & 4.8 & 5.5 & 6.1 \\
\hline Pupa & - & - & - & 39.0 & 45.0 & 55.0 & - & - & - \\
\hline
\end{tabular}

1 Data obtained from 69 specimens.

2 Data obtained from 20 fresh-killed specimens preserved in 70 percent alcohol.

3 Data obtained from 20 fresh-killed specimens (per instar) in KAAD and preserved in 70 percent alcohol.

${ }^{4}$ Data obtained from 73 specimens.

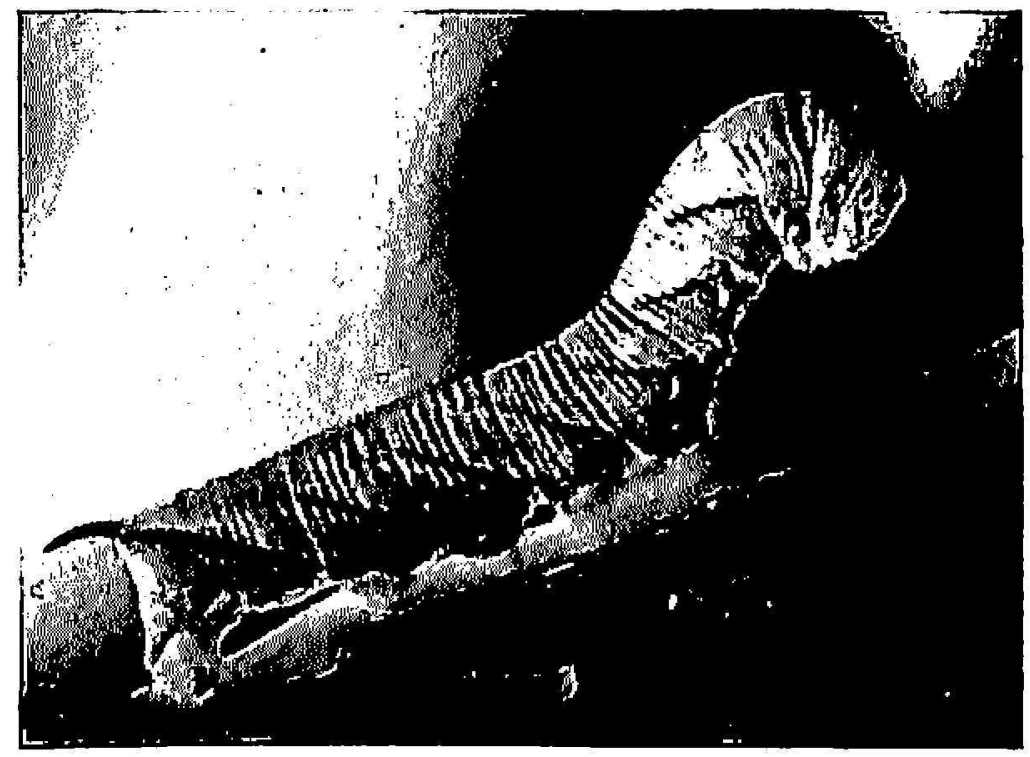

FIG. 2.-Full-grown larva of tobacco hornworm.

as long as the body, but is reduced to about $\frac{1}{3} 3$ of its body length by the time of first moult. The body segments are demarked by faint white lines at the end of this instar. According to Wolcott (22) the hatched larva weighs $0.0004 \mathrm{~g}$. 'The average leaf consumption per first instar larva was $0.8 \mathrm{~cm}^{2}$. 
Taвsl: 2.-Duration of slages of the tobaceo hornworm (Manduea sexta (L.)), A pril and llay 1973

\begin{tabular}{lrrrrrr}
\hline & \multicolumn{6}{c}{ Duration of stages (days) } \\
\cline { 2 - 7 } Stage & \multicolumn{7}{c}{ April } & \multicolumn{1}{c}{ May } \\
\cline { 2 - 7 } & Nin. & Ave. & Max. & Min. & Ave. & Max. \\
\hline Egg & - & - & - & $3^{1}$ & 4.5 & 6 \\
Larvae & & & & & & \\
1st & 2 & 3.6 & 6 & $2^{1}$ & 3.0 & 4 \\
2nd & 2 & 3.4 & 6 & 2 & 2.7 & 3 \\
3rd & 2 & 3.8 & 6 & 3 & 3.0 & 3 \\
4th & 3 & 5.1 & 8 & 3 & 3.6 & 4 \\
5th & 8 & 11.7 & 15 & 4 & 5.2 & 6 \\
Prepupa & - & - & - & $4^{4}$ & 5.3 & 7 \\
Pupa & 19 & 23.5 & 27 & $19^{\circ}$ & 21.0 & 24 \\
Adult & 2 & 4.5 & 7 & $3^{6}$ & 4.6 & 5 \\
\hline
\end{tabular}

${ }^{1}$ Data obtained from 10 specimens.

2 Data obtained from 69 specimens for all larval instars.

3 Includes prepupal period.

4 Data obtained from 8 specimens.

5 Data obtained from 30 specimens.

${ }^{6}$ Data obtained from 7 specimens.

\section{Second Instar}

The appearance of faint, oblique white stripes on the caudal portions of the pleura is the important change undergone by the larva during this phase. The average leaf consumption per second instar larva was $3.6 \mathrm{~cm}^{2}$.

\section{Third Instar}

The principal characteristic in this phase is the appearance of black stripes associated with the white ones which developed in the previous instar. The whitish tubercles on the dorsal surface of the body become more visible and distinct. The spiracles can be very casily pereeived by the naked eye. The average leaf consumption per third instar larva was 19.0 $\mathrm{cm}^{2}$.

\section{Fourth Instar}

The black and white stripes on the pleura are fully demarked during this instar. Larvar in this instar closely resemble full-grown larva in general color and appearance. The dorsocaudal horn is now pigmented with a whitish-red coloration. The average leaf consumption for this instar was $87.3 \mathrm{~cm}^{2}$. 


\section{Fifth Instar}

The larva attains full size in this instar. It usually is of various shades of green, with seven black and white oblique stripes on the pleurae of the first seven abdominal segments. The spiracles are surrounded by areas of dark-red to light-brown. It weighs from 5 to $6 \mathrm{~g}$ when full-grown according to Wolcott (25). The average leaf consumption per larva in this instar was $704.5 \mathrm{~cm}^{2}$.

TABL: 3.-Leaf arca consumption of the tobacco hormworm, Manduca sexta (L.), May 1973

\begin{tabular}{crrr}
\hline \multirow{2}{*}{ Larval instars } & \multicolumn{3}{c}{ Area of leaf consumed $\left(\mathrm{cm}^{2}\right)$} \\
\cline { 2 - 4 } & Ninimum & Average & Maximum \\
\hline 1st & 0.3 & 0.8 & 1.0 \\
2nd & 1.0 & 3.6 & 9.0 \\
3rd & 14.0 & 19.0 & 25.0 \\
4th & 75.0 & 87.8 & 105.0 \\
5th & 528.0 & 704.5 & 847.3 \\
\hline
\end{tabular}

1 Data based on 10 specimens in each instar.

\section{Prepupal Period}

Some of the visible external changes which take place during this period are a reduction in body length accompanied by an increase in width, change of the green color to a light-brown one, stoppage of feeding and proleg deterioration. The secretion of moulting fluid for softening the external tissues is visible through the pre-pupal tissue; the splitting dorsally of the tissue from the head to the dorsocaudal horn oceurs at the end of this phasc. This stage lasts for 2 to 7 days, averaging 5.3 (table 2).

\section{PUPAL STAGE}

The pupa is of the obtect type, with the proboscis case bent sharply backward, the tip touching the sternum about one-third of the distance from the base to the end of the abdomen. The wings extend about half the distance to the posterior end of the body (figs. 3,A and 3,13). When first formed, the pupal case is bright yellowish-green, but during the succeeding '24 hours it changes to light-brown, and later to dark-brown. The sexes can be determined by two small protuberances located in the fomale in the sth segment at the sides of the genital opening and in the male in the 9th segment (fig. 3,()). The pupa averages $45 \mathrm{~mm}$ in length. The duration of stage varied from 19 to 27 days (tables 1 and 2 ). 


\section{ADULT STAGE}

The general color of the dorsal surface of the body and forewings of the moth is a dark brownish-gray. The thorax is marked with several white spots with black rings. The forewings have a slight variegated appearance, owing to the presence of a number of wavy, dark-brown transverse bands. There is a broad white spot at the base of each forewing, and a smaller
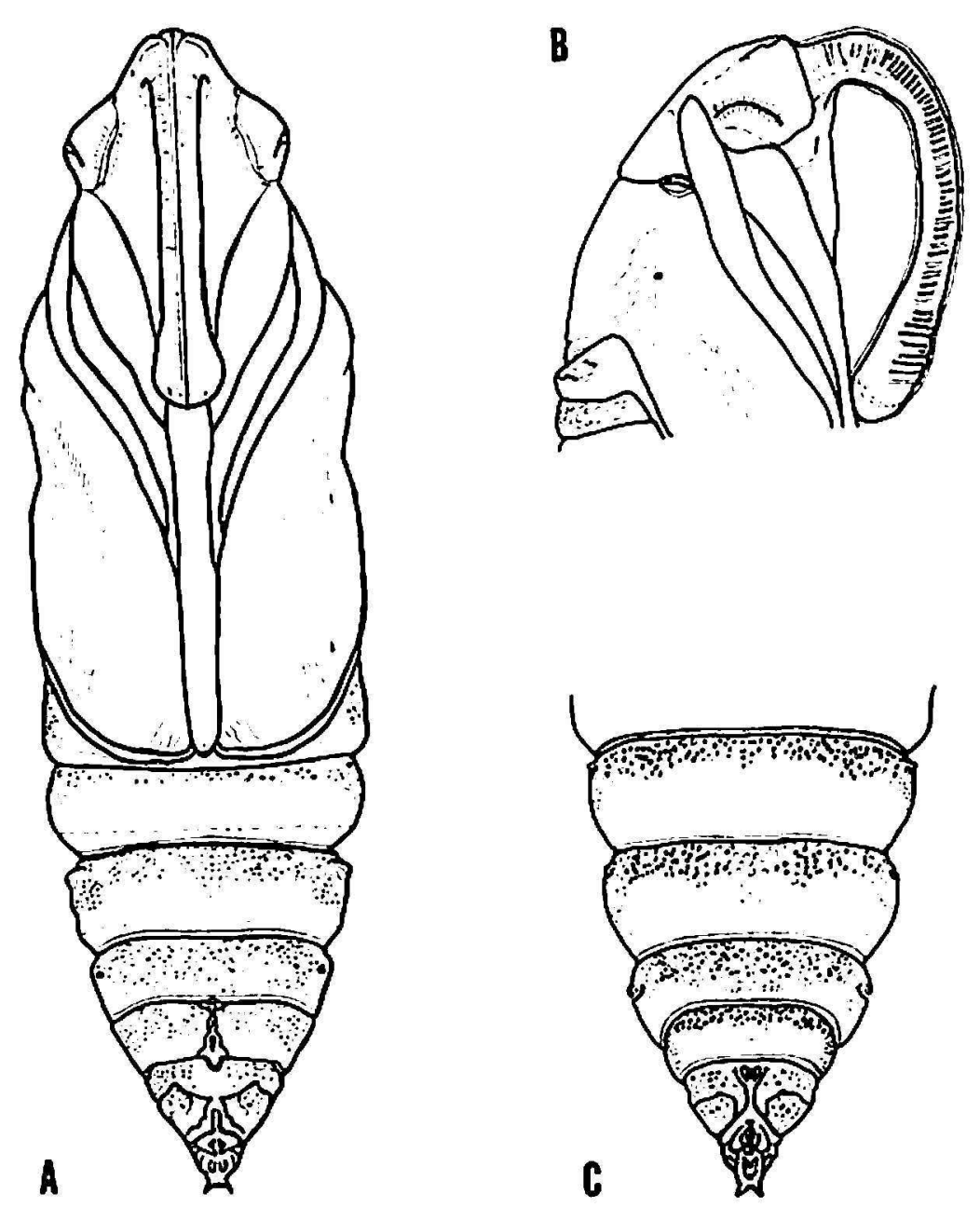

Fic. 3. - Pupa of tobacro hornworm. A, ventral view (female); B, head, lateral view; C, abdomen (male) ventral view.

white spot at the end of each discal cell. The outer margins of the forewings are fringed with short, dark-brown scales, among which several white tufts occur. The hind wings are darker and are traversed by a number of broken, oblique cross bands of white and dark-brown scales. A short fringe of whitish scales spotted with brown occurs on the outer margins. Two lateral black spots oceur on the dorsal surface at the base of the abdomen, and the six suecerding segments are marked with six pairs of orange spots becoming progressively smaller toward the tip of the abdomen; these are 
associated with a pair of median white spots. The number of orange spots is not always constant, and specimens occasionally have five pairs instead of the normal six. The ventral surface of the wings is light brownish-gray in color and is crossed by a few dark-brown bands. The ventral surface of the body is gray, with three or four medium dark-brown spots on the abdomen. The palpi and the ventral surface of the thorax are heavily clothed with long hairlike bristles. The males usually are smaller than the females but are similar in appearance. The antennae of the male are much larger and pectinate in comparison to those of the female which are filiform. The life span of the adult moth under laboratory conditions varied from 2 to 7 day's (fig. 4 and table 2).

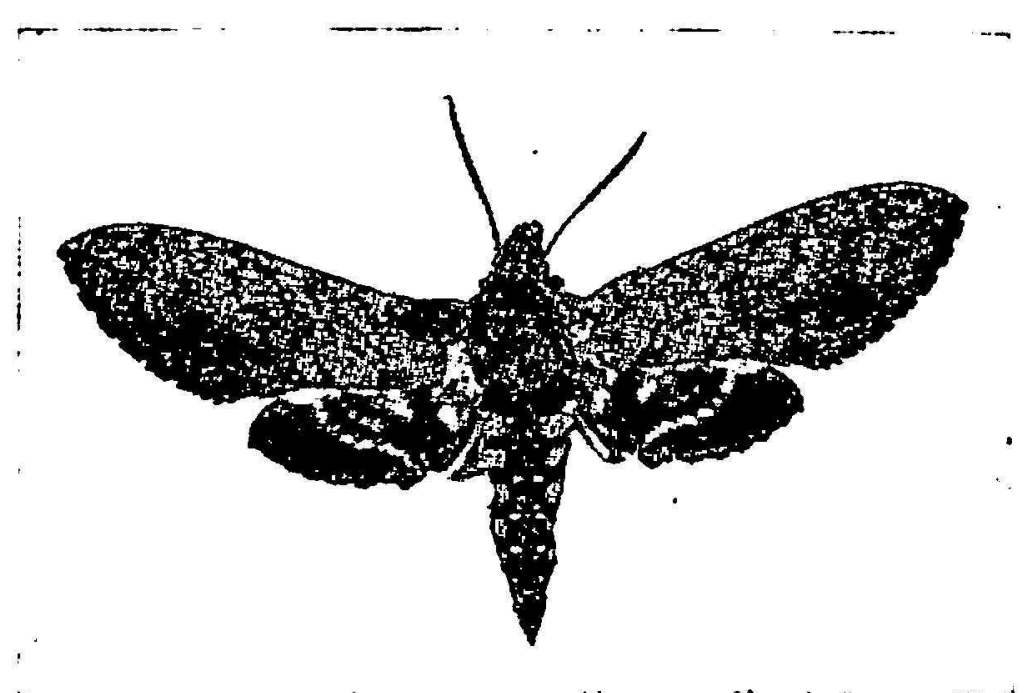

Fig. 4.-Adult of the tobacco hornworm.

HOST PLANTS

The hornworm also attacks tomato, Lycopersicon esculentum; sweet pepper, Capsicum annuum; eggplant, Solanum melongena; as well as tobacco, Nicoliana labacum, among the cultivated solanaccous species. It is scldom a serious threat to crops other than tobacco. The common "berenjena cimarrona", Solanum ficifolium, is one of its wild alternate hosts.

\section{NATURAL ENEMIES}

Approximately 23 insect species have been recorded as predators or parasites of Manduca sexta in the southern part of the United States according to Lawson ( 8 ) and to Madden and Chamberlain (11); 18 of them occur in Puerto Rico. Only threc are reported by Wolcott (25) as locally effective in hornworm control. Vespids of the genus Polistes were seen by Pérez-Escolar and Medina Gaud (12) to attack caterpillars in tobacco 
fields at the Gurabo Substation. The senior author recently confirmed that Polistes crinitus Felton feeds on small hornworm larvae at the same locality.

Tobacco foliage is unfavorable for egg parasites according to Rabb and Bradley (14). Its sticky surface causes a natural reduction of parasitism to Telenomus minulum and T. sphingis, both known enemies of the tobacco hornworm. The latter species has been recorded from Puerto Rico.

\section{LIST OF NATURAL ENEMIES OF THE TOBACCO HORNWORM IN PUERTO RICO}

CLASS AVES

Order Passeriformis

PAMILY ICTERIDAE

1. Icterus dominicensis portoricensis (Bryant)-the l'ucrto Rican blackcowled oriole, recorded by Wolcott (20).

2. Quiscalus niger brachypterus (Cassin)-the Pucrto Rican Greater Antillean grackle or "mozambique", recorded by Wolcott $(18,20,24,25,26)$.

CLASS INSECTA

Order Diptera

FAMILY CERATOPOGONIDAE

3. Forcipomyia fuliginosa (Meigen)-This fly species has been seen feeding voraciously on tobacco hornworm larvae by Dr. R. T. Cotton and is listed in synonymy as $F$. eriophora (Williston) by Wolcott (25).

\section{Order Hymenoptera}

PAMILY BRACONIDAE

4. Apanteles americanus (Lepeletier)-This parasite rarely attacks tobacco hornworm larvae but has been recorded on this and other hosts in Pucrto Rico (25).

FAMILY ICHNEUMONIDAE

5. Enicospilus flavosculellatus (Brullé) listed as E. thoracicus (Cresson) has been reared locally from the tobaceo hornworm (25).

FAMILY SCELONIDAE

6. T'elenomus sphingis Ashmead-an egg parasite of this insect, is not sufficiently abundant in Puerto Rico to be of much value in the natural 
control of the pest. Also recorded from the United States by Lawson (8) and Madden and Chamberlain (11).

\section{FAMILY VESPIDAE}

7. Polistes crinitus Felton-attacks caterpillars in the field; reported as Polistes spp. by Pérez-Escolar and Medina Gaud (12).

\section{CLASS REPTILIA}

\section{Order Squamata}

\section{FAMILY IGUANIDAE}

8. Anolis cristatellus Duméril \& Bibron-According to Rosenfeld (15) this little lizard attacked an adult tobacco hornworm and killed it after a short fight.

\section{RESUMEN}

Durante el año 1973 se realizó un estudio del ciclo de vida del cornudo o gusano verde del tabaco en Puerto Rico (Manduca sexta (L.), (=Protoparce sexta Joh.). El trabajo incluye descripciones de todos los estadios del ciclo de vida de este insecto, mediciones de las cápsulas cef́́licas de las larvas y la cantidad de tejido foliar (en centímetros cuadrados) que consumieron las larvas en los diferentes estadios. También se incluye una lista de plantas hospedadoras y otra de los enemigos naturales del insecto en Puerto Rico.

\section{LITERATURE CITED}

1. Anonymous, Anuario de estadísticas agrícolas de Puerto Rico 1971-72, Oficina de Estadísticas Agrícolas, Depto. de Agricultura, pp. 44, junio 1972.

2. Barrett, O. W., Report of the Entomologist and Botanist, In Ann. Rpt. P.R. Agr. Expt. Sta. for 1804, (Ann Rept. Office Expt. Stations, June 30, 1904) Washington, D.C., pp. 378-99, 1905.

3. Busck, A., Notes on a brief trip to Porto Rico in January and February, 1889 USDA Bur. Entomol. Bull. (N.S.) 22: 88-92, 1900.

4. Cotton, R. T., Insects attacking vegetables in Porto Rico, J. Dept. Agr. P.R. 2 (4) : 265-317, 1919.

5. Dewitz, H., Dammerungs und Nachtfalter von Porto Rico, Mitteilungen des Münchner, Ent. Vereines, Munich, 1: 91-6, 1877.

6. Gundlach, J., Fauna Puerto-Riqueña, Ann. Soc. Española Hist. Nat. Vol. 16-22 Madrid, Mayo 31, 1887 a Enero 31, 1894 (Insects pp. 347-658) 1887.

7. Jones, T. H., Insects affecting vegetable crops in Porto Rico, USDA Bull. 192: $1-11,1915$.

8. Lawson, F. R., The natural enemies of the hornworms of tobacco (Lepidoptera: Sphingidae), Ann. Ent. Soc. Amer. 52 (5) : 741-755, 1959.

9. Leonard, M. D., Report of the Division of Entomology for the Fiscal Year 1929-30, Ann. Rpt. Ins. Expt. Sta., 1929-30, San Juan, P.R., pp. 110-23, 1931.

10. - Insect conditions in Puerto Rico during the fiscal year, July 1930 through June 30, 1931, J. Dept. Agr. P.R. 16 (2) : 121-44, 1932. 
11. Madden, A. H. and Chamberlain, F. S., Biology of the tobacco hornworm in the southern cigar-tobacco district, USDA Tech. Bull. 896: 1-51, 1945.

12. Medina Gaud, S. and Pérez-Escolar, M., Personal communication, June 1973.

13. Möschler, H. B., Die Lepidopteren-Fauna der Insel Portorico, Abhandl. Seckenb. Naturforsch. Ges., Frankfurt, 16: 69-360, 1890.

14. Rabb, R. L. and Bradley, J. R., The influence of host plants on parasitism of eggs of the tobacco hornworm, J. Econ. Entomol. 61 (5): 1249-52, 1968.

15. Rosenfeld, A. H., The food of Porto Rican lizards, J. Econ. Entomol. Scientific Notes 18: 422-23, 1925.

16. Stahl, A., Fauna de Puerto Rico, Insectos, pp. 82-102 y 169-213, San Juan, P.R., 1882.

17. Tower, W. V., Reports of the Entomologist and Plant Pathologist, In Ann. Rpt. P.R. Agr. Expt. Sta., Washington, D.C. 1907, pp. 31-8, 1908.

18. Wolcott, G. N., Los gusanos de la hoja del tabaco, Est. Expt. Insular, Rio Piedras, P.R., Circ. 53: 1-15, 1922.

19. - Insectae Portoricensis. A preliminary annotated check-list of the insects of Porto Rico, with descriptions of some new species, J. Dept. Agr. P.R. 7 (1): $153,1923$.

20. —, Entomología económica puertorriqueña, Est. Expt. Insular, Río Piedras, P.R., Bol. 32: 1-176, 1924.

21. - The food of Porto Rican lizards, J. Dept. Agr. P.R. 7 (4) : 5-37, 1924.

22. - On the amount of food eaten by insects, J. Dept. Agr. P.R. 9 (1): 47-58, 1925.

23. - An economic entomology of the West Indies, Entomol. Soc. P.R., San Juan, P.R., pp. 688, 1933.

24. - "Insectae Borinquenses" A revised annotated checklist of the insects of Puerto Rico, J. Agr. Univ. P.R. 20(1): 446-7, 1936.

25. —, The insects of Puerto Rico, J. Agr. Univ. P.R. 32 (3) : 626-8, 1948.

26. —-, Entomología económica puertorriqueña, Est. Exp. Agr. Bol. 125: 102-7, 1955. 